\title{
AN ANALYSIS OF ADOPTION BEHAVIOUR OF GLORIOSASUPERBA IN TIRUPUR DISTRICT
}

\author{
KARTHIKEYAN V. ${ }^{1}$ \& PREMAVATHI R. ${ }^{2}$ \\ ${ }^{1}$ PG Scholar, Department of Agricultural Extension and Rural Sociology, Tamil Nadu Agricultural University, \\ Coimbatore, India \\ ${ }^{2}$ Associate Professor (Agricultural Extension), Directorate of Extension Education, Tamil Nadu Agricultural University, \\ Coimbatore, India
}

\begin{abstract}
Tamil Nadu leads in production of Gloriosasuperba in India with an estimated area of 3000 hectares with annual production of 1000 ton dry seed. Gloriosa superba are the main medicinal plants grown in Tamil Nadu. Because of its high returns, Gloriosasuperba is known as a cash crop like sugar cane and cotton. This study was conducted in Tirupurdistrict of Tamil Nadu and it contains of 13 blocks in that Mulanur blockwas selected purposively based on maximum area under Gloriosasuperba.Four villages namely, Kilangundal, Kumarapalayam, Mulanur and Chinnamaruthur from Mulanur block were selected based on the maximum area under Gloriosasuperba. As well as a greater number of Gloriosa superba growers. The results indicated that majority of the respondents possess medium to high level of knowledge on recommended package of practices of Gloriosasuperba. Among allthe practices season of planting, broad row method of planting, fencing with GI wires and drip method of irrigation were fully adopted by most of the Gloriosasuperba growers.

KEYWORDS: Adoption Behaviour, Crop Production, Gloriosasuperba, Crop protection, Post-Harvest
\end{abstract}

Received: Dec 21, 2020; Accepted: Dec 31, 2020; Published: Jan 13, 2021; Paper Id.: IJASRDEC202012

\section{INTRODUCTION}

India is an agrarian country where majority of the people are held with agriculture as their major income source. When a farmer finds out their potential customer linkage, the effective agricultural marketing system would be achieved. Being an important field, agriculture contributes to Indian economy in a larger way. The plants that are rich in secondary metabolites and are potential drug sources are medicinal plants. Secondary metabolites contain alkaloids, glycosides, coumarins, flavonoids, steroids etc. Medicinal plants are the primary source of the development of Indian medicinal systems (Ayurveda, Unani, Siddha and Homeopathy). These plants are found in distinct environmental and climatic conditions in different parts of the country. With over 80 per cent of the world's biodiversity, including medicinal plant genetic diversity, India has tremendous potential to occupy a major global market place for herbal formulations, medicines, and medicinal plant-based products. The international market place for herbal products is predicted to gain a market size of US\$ 5 trillion by the end of 2050.Almost 80 per cent of the contribution to the global supply of medicinal plants has been controlled by India and China alone.

Tamil Nadu leads in production of Gloriosasuperba in India with an estimated area of 3000 hectares with annual production of 1000 ton dry seed. The Gloriosasuperba crop is mainly cultivated in Maharashtra, Tamil Nadu, Kerala, Rajasthan, Karnataka, Goa, and other states in India. Medicinal and aromatic plants are cultivated in Tamil Nadu at an area of about 13,727 hectares during the year 2020 (Department of Horticulture and Plantation Crops, 2020). Gloriosa superba are the main medicinal plants grown in Tamil Nadu. 
"Gloriosa Superba" is Zimbabwe's national flower and also Tamil Nadu's state flower. Because of its high returns, Gloriosasuperba is known as a cash crop like sugar cane and cotton. It is used in the healing of gout, a widespread disease in the temperate regions of the globe. The quality of colchicine ranges from ' 0.15 per cent to 0.3 per cent in rhizomes and 0.7 per cent to 0.9 per cent' in seeds. The present study discusses the adoption of growers of Gloriosa Superba and also the limitations of current marketing structures that would provide a better understanding of the marketing of Gloriosasuperba.

This will help the people involved in selling Gloriosasuperba to chalk out a strategy based on need.The research will be very helpful in creating appropriate knowledge of essential technologies, enhancing of Gloriosasuperba growers marketing structure and marketing behaviour.

\section{MATERIALS AND METHODS}

Ex-post facto research design will be used in this study which will suit the objectives and type of information needed. Among 38 districts in Tamil Nadu,Tirupur district was purposively selected for this study as it ranks $1^{\text {st }}$ among the largest area under Gloriosasuperba cultivation in Tamil Nadu.Tirupur district has 13 blocks in that Mulanur blockwas selected purposively based on maximum area under Gloriosasuperba. Four villages namely, Kilangundal, Kumarapalayam, Mulanur and Chinnamaruthur from Mulanur block were selected based on the maximum growers under Gloriosa Superba.

From the four villages selected, the area under Gloriosasuperba was calculated. Out of the total farmer under Gloriosasuperba, 30.00 per cent of the farmerswereselected for conducting survey. The 30.00 per cent of the selectedGloriosasuperba growers was shared by 121 farmers. So, a total of 121 farmers have been selected as respondents using Proportionate Random Sampling Method (PRSM). Data will be collected by using a well-structure and pre-tested interview schedule. Individual contact method was used to collect data. Suitable statistical analysis was used to interpret data and derived meaningful conclusion.

\section{THE VILLAGE WISE DISTRIBUTION OF RESPONDENTS FOR THE STUDY IS GIVEN BELOW}

Table 1: Block and Village wise Distribution of Respondents

\begin{tabular}{|l|l|l|c|c|}
\hline \multirow{2}{*}{ S.No } & \multicolumn{1}{|c|}{$\begin{array}{c}\text { Name of the } \\
\text { Block }\end{array}$} & \multicolumn{1}{|c|}{ Name of the Village } & $\begin{array}{c}\text { No. of } \\
\text { Farmers }\end{array}$ & $\begin{array}{c}\text { No. of Respondents } \\
\text { Selected }\end{array}$ \\
\hline \multirow{4}{*}{1} & \multirow{3}{*}{ Mulanur } & Kilangundal & 1186 & 40 \\
\cline { 3 - 5 } & Kumarapalayam & 856 & 29 \\
\cline { 3 - 5 } & Mulanur & 737 & 25 \\
\cline { 3 - 5 } & Chinnamaruthur & 798 & 27 \\
\hline \multicolumn{2}{|l}{ Total } & $\mathbf{3 5 7 7}$ & $\mathbf{1 2 1}$ \\
\hline
\end{tabular}

\section{RESULTS AND DISCUSSION}

In this study Adoption behaviour was studied under differentheadings viz., Season, Field preparation, Planting Material used, Planting method, Irrigation, Manuring, Fencing Standards, Pollination, Crop protection, weed management, Harvest, Post-harvest.

Table 2: Distribution of the Respondents according to their Overall Adoption Behaviour of Cultivation Technologies $(\mathbf{n}=121)$

\begin{tabular}{|c|c|c|c|}
\hline S. No. & Category & No & Per cent \\
\hline 1 & Low & 15 & 14.40 \\
\hline 2 & Medium & 84 & 66.40 \\
\hline 3 & High & 22 & 19.20 \\
\hline & Total & 121 & 100 \\
\hline
\end{tabular}


From the above Table 2 it was observed that less than two- thirds $(66.40 \%)$ of the respondents had medium level of adoption followed by high (19.20\%) and low (14.40\%) levels.

Majority of the respondents were cultivating Gloriosasuperba in the study area and were selling their produce to the commission agent. In turn, commission agent is demanding more of Gloriosa Superbaseed because of the trader's preference towards it. High market rate in a foreign country, high medicinal value,traders'preference towards seed leads to bulk procurement may be the reason for medium level of adoption.

\section{Season}

This Table 3 revealsthat, Season plays a major role in Gloriosa Superbacultivation, majority of the respondents (99.2\%) had planted Gloriosa Superba during the season of June-July. Generally, this season coincides with the onset of southwest monsoon and also received more rainfall in this time, so the farmers being adopting this season. In both rainfed and irrigated areas, this season is considered by natives as an ideal season to begin farming operations.

\section{Field Preparation}

From the Table 3, it can be inferred that the little more thanhalf of the respondents (50.4\%) partially adopted the practice of ploughing (2-3 times) in their field until it comes to a fine tilth and all grass stubbles, root, etc., should be removed from the field. It could be seen from the above table that about (49.6\%) of respondents were partially adoptedthe recommend ploughing because without ploughing we can't plant a tuber in the field. In the case of FYM, more than half (55.4\%) of the respondents were partially adopted the FYM @10t/ha after ploughing due to low availability of FYM.The reason for application of FYM is it increases soil fertility and natural source of available nitrogen to the Gloriosasuperba. TheGloriosasuperba growers by planting the tubers, ploughing the field across the slope during summer, so that the hardcrusted upper layer of the soil breaks and it improved the soil structure.

\section{Planting material}

It could be from the Table 3, observed a little more than half $(55.4 \%)$ of the respondents partially adopted the practise in regard to the planting material of rhizomes in " $\mathrm{V}$ ', shape. It is seen that planting $2000 \mathrm{~kg}$ tuber per hectare area is ideal and little more than three-fifth $(62 \%)$ of the respondents partially adopting because pest like borers infect tubers, so that tuber weight of $40-60 \mathrm{~g}$ is recommended and it's adopted by almost three-fifth $(59.5 \%)$ of the respondents because its sprout well.

More than half $(57.0 \%)$ of respondentsadopting the treatments of tubers with 0.1 per cent carbendazim for half an hour for controlling tuber rot andsoil worms.

\section{Planting Method}

It could be inferred from theTable 3, that majority $(91.7 \%)$ of the respondents adopted the broad row method of the plant due to the fact that tuber is well sprout in broad row method

It could be seen that spacing $(30-45 \mathrm{~cm})$ along the rows was partially adopted by majority $(65.3 \%)$ of the farmers followed by 28.1 per cent of the growers were not adopting the spacing $(30-45 \mathrm{~cm})$ due to lack of awareness about recommend spacing. Farmers think that if theyplant more tubers, they will get more yield. 


\section{Irrigation}

It could be seen from the Table.3, as compared to the irrigation methods of flood irrigation and drip irrigation, majority of the farmers were $(92.6 \%)$ adopted the practice of drip irrigation as they found that, this method was suitable to their farms, due to the water scarcity and low rainfall. And an irrigation interval of 4-7 days during initial period and later on at an interval of 15 days were followed by majority of the respondents $(76.2 \%)$ because the crop needs life irrigation for $1^{\text {st }}$ three days and weekly interval of scheduled irrigation.

\section{Manuring}

From the Table 3, show that the level of adoption of nutrient management practices like application of NPK at $120: 50: 75 \mathrm{~kg} / \mathrm{ha}$ were observed among almost three-fourth $(74.4 \%)$ of the respondents partially adopted because they adopting their own practice of manuring. About (62.8\%) farmers were adopted applying in two split doses of NPK by growers because the nitrogen helps for vegetative growth (leaf and stem) and phosphorus helps for root formation and potassium for increasing the disease resistance.

Other nutrient management practices like application of vermicompost and biofertilizer were not adopted by more than half of the respondents $(58.7 \% \& 56.2 \%)$ respectively. Because they were applying the FYM instantly and unavailability of vermicompost and biofertilizer is reason for not adoption.

Table 3: Distribution of the Respondents according to the Adoption behaviour of Cultivation Technologies

\begin{tabular}{|c|c|c|c|c|c|c|c|c|}
\hline $\begin{array}{l}\text { S. } \\
\text { No }\end{array}$ & \multicolumn{2}{|r|}{ Cultivation Technology } & \multicolumn{2}{|c|}{$\begin{array}{c}\text { Fully } \\
\text { Adopted }\end{array}$} & \multicolumn{2}{|c|}{$\begin{array}{l}\text { Partially } \\
\text { Adopted }\end{array}$} & \multicolumn{2}{|c|}{$\begin{array}{c}\text { Not } \\
\text { Adoption }\end{array}$} \\
\hline & & & Zu & 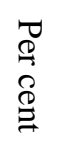 & ZZ & 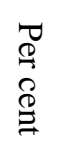 & ZZ & 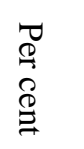 \\
\hline $\mathbf{A}$ & \multicolumn{2}{|c|}{ Crop production Technologies } & & & & & & \\
\hline 1. & Season & June-July & 120 & 99.2 & 1 & 0.8 & 0 & 0 \\
\hline \multirow[b]{2}{*}{2.} & \multirow{2}{*}{$\begin{array}{l}\text { Field } \\
\text { preparation }\end{array}$} & Ploughing (2 to 3 times) & 60 & 49.6 & 61 & 50.4 & 0 & 0 \\
\hline & & $\begin{array}{l}\text { Application of FYM@ 10t/ha after } \\
\text { ploughing }\end{array}$ & 52 & 43.0 & 67 & 55.4 & 2 & 1.7 \\
\hline \multirow{4}{*}{3.} & \multirow{4}{*}{$\begin{array}{l}\text { Planting } \\
\text { Material used }\end{array}$} & Propagation through ' $\mathrm{V}$ ' shaped tubers & 46 & 38.0 & 67 & 55.4 & 8 & 6.6 \\
\hline & & $2000 \mathrm{~kg}$ tubers/hectare & 39 & 32.2 & 75 & 62.0 & 7 & 5.8 \\
\hline & & Recommended tuber weight 40-60g. & 72 & 59.5 & 49 & 40.5 & 0 & 0 \\
\hline & & $\begin{array}{l}\text { Treatment of tubers with } 0.1 \% \\
\text { Carbendazim for half an hour for } \\
\text { controlling Tuber rot. }\end{array}$ & 69 & 57.0 & 45 & 37.2 & 7 & 5.8 \\
\hline \multirow{3}{*}{4.} & \multirow{3}{*}{$\begin{array}{l}\text { Planting } \\
\text { method }\end{array}$} & Channel method & 8 & 6.6 & 2 & 1.7 & 111 & 91.7 \\
\hline & & Broad row method & 111 & 91.7 & 9 & 7.4 & 1 & 0.8 \\
\hline & & Spacing $(30-45 \mathrm{~cm})$ & 8 & 6.6 & 79 & 65.3 & 34 & 28.1 \\
\hline \multirow[b]{3}{*}{5.} & \multirow[b]{3}{*}{ Irrigation } & Flood irrigation & 10 & 8.3 & 3 & 2.5 & 108 & 89.3 \\
\hline & & Drip irrigation & 112 & 92.6 & 6 & 5.0 & 3 & 2.5 \\
\hline & & $\begin{array}{l}\text { An irrigation interval of } 4-7 \text { days during } \\
\text { initial period and later on at an interval of } \\
15 \text { days }\end{array}$ & 92 & 76.0 & 27 & 22.3 & 2 & 1.7 \\
\hline 6. & Manuring & NPK 120:50:75kg/ha & 12 & 9.9 & 90 & 74.4 & 19 & 15.7 \\
\hline
\end{tabular}




\begin{tabular}{|c|c|c|c|c|c|c|c|c|}
\hline & & Applied in two split doses & 76 & 62.8 & 30 & 24.8 & 15 & 12.4 \\
\hline & & Application of Vermicompost @ 5t/Ha & 39 & 32.2 & 11 & 9.1 & 71 & 58.7 \\
\hline & & Biofertilizers & 31 & 25.6 & 22 & 18.2 & 68 & 56.2 \\
\hline 7. & $\begin{array}{l}\text { Fencing } \\
\text { Standards }\end{array}$ & GI wires & 116 & 95.9 & 3 & 2.5 & 3 & 1.7 \\
\hline \multirow[b]{2}{*}{8.} & \multirow[b]{2}{*}{ Pollination } & Hand pollination & 106 & 87.6 & 12 & 9.9 & 3 & 2.5 \\
\hline & & $\begin{array}{l}\text { Foliar spray of } 0.1 \% \text { Boron and } 0.5 \% \\
\text { Zinc sulphate }\end{array}$ & 49 & 40.5 & 62 & 51.2 & 10 & 8.3 \\
\hline \multirow{2}{*}{9.} & \multirow{2}{*}{$\begin{array}{l}\text { Crop } \\
\text { protection }\end{array}$} & $\begin{array}{l}\text { Leaf eating caterpillar } \\
\text { Spray } 0.2 \% \text { Dichlorovas }\end{array}$ & 69 & 57.0 & 50 & 41.3 & 2 & 1.7 \\
\hline & & $\begin{array}{l}\text { Tuber rot } \\
\text { Drench } 2 \mathrm{~g} \text { of } \mathrm{COC} / 1 \text { lit of water }\end{array}$ & 13 & 10.7 & 91 & 75.2 & 17 & 14.0 \\
\hline \multirow{2}{*}{10.} & \multirow{2}{*}{$\begin{array}{l}\text { Weed } \\
\text { management }\end{array}$} & Periodical Weeding & 6 & 5.0 & 10 & 8.3 & 105 & 86.8 \\
\hline & & Hand weeding & 108 & 89.3 & 8 & 6.6 & 5 & 4.1 \\
\hline \multirow[b]{2}{*}{11.} & \multirow[b]{2}{*}{ Harvest } & $160-180$ days after sprouting of tubers. & 65 & 53.7 & 55 & 45.5 & 1 & 0.8 \\
\hline & & $\begin{array}{l}\text { When the capsule starts turning light } \\
\text { green from dark green and skin of the } \\
\text { fruit shows shrunken appearance and } \\
\text { becomes light in weight. }\end{array}$ & 106 & 87.6 & 14 & 11.6 & 1 & 0.8 \\
\hline \multirow{3}{*}{12.} & \multirow{3}{*}{ Post-harvest } & Drying (7-10 days) & 109 & 90.1 & 12 & 9.9 & 0 & 0 \\
\hline & & Threshing (5-6 days) & 93 & 76.9 & 28 & 23.1 & 0 & 0 \\
\hline & & Cleaning & 105 & 86.8 & 15 & 12.4 & 1 & 0.8 \\
\hline
\end{tabular}

\section{Fencing Standards}

The results presented in Table 3, being a climber, Gloriosa Superbaneeds supports, which may be done using GI wire, and majority of the growers (95.9\%) had adopted due to long life of GI wire and it sub stand weight of the plant for period.

\section{Pollination}

It could be understand from the Table 3, that majority of the growers (87.6\%) had adopted the practice of hand pollination for increasing the fruit setting, followed by little more than half (51.2\%) of the respondents have been partially adopted foliar spray of 0.1 percent boron +0.5 percent zinc sulphate at fortnight interval to induce higher seed rate because they don't have any idea about foliar spray. And nearly half (49.0\%) of the growers were fully adopted the foliar spray of 0.1 per cent Boron and 0.5 per cent Zinc sulphate because it plays a key role in functioning of a cell wall.

\section{Crop Protection}

Regarding crop protection, it could be inferred that little more than half (57\%) of the respondents have controlled leaf eating caterpillar by spraying dichlorvos 0.2 per cent. Followed by $(41.3 \%)$ of respondents were partially adopted due to lack of knowledge about the exact quantity of recommend pesticides.

Drenching $2 \mathrm{~g} \mathrm{COC} / 1$ litre of $\mathrm{H}_{2} \mathrm{O}$ to control tuber rot have been partially adopted by majority (75.7\%) of the respondents because they were already applied in the form of 0.1 per cent Carbendazim to control the tuber rot.

\section{Weed Management}

The Table 3 concluded that with respect to weed management, majority of the respondents (89.3\%) adopted hand weeding. Itis better to remove weed in the field, for better observant of water. Majority of (86.8\%) respondents were not adopted the periodical weeding because Gloriosa Superbais a climbing herb so the level of weeding is low. 


\section{Harvest}

Table 3, indicates that majority of the growers (87.6\%) had harvested their produce when the capsule start turning light green from dark green \& skin of the fruit shows shrunken appearance \& light in weight due to visible nature of the symptom.

A little more than half of the respondents $(53.7 \%)$ had adopted harvesting the produce or pods, when the crop duration is $160-180$ days.

\section{Post-Harvest}

From the results depicted in Table 3, majority of the growers $(90.1 \%)$ had practised adopting post-harvest technologies like drying (7-10 days) in a sun light. And about three-fourth (76.9\%) of the respondents have adopted the threshing (5-6days) to facilitate separation of seeds from low lier and cleaning was adopted by majority $(86.8 \%)$ of respondents to remove sand, stone \& other unwanted particles.

\section{CONCLUSIONS}

This present study clearly shows that the majority of the respondents (66.40\%) fall under medium to high level of adoption. This is due to the reason that majority of the respondents possess medium to high level of knowledge on recommended package of practices of Gloriosasuperba. Among allthe practices season of planting, broad row method of planting, fencing with GI wires and drip method of irrigation were fully adopted by most of the Gloriosasuperba growers. The findings and implication of this research study may serve as good source of supportive information for the state department of horticulture and other line departments, to devise strategies to improve the cultivation practices of Gloriosasuperba.

\section{REFERENCES}

1. Adnan,Nadia, Shahrina Md Nordin, and Zulqarnain bin Abu Bakar. "Understanding and Facilitating Sustainable Agricultural Practice: A Comprehensive Analysis of Adoption Behaviour among Malaysian Paddy Farmers." Land Use Policy 68 (2017): 372-82.

2. Chaya, Wirawat, Boosya Bunnag, and Shabbir H Gheewala. "Adoption, Cost and Livelihood Impact of Machinery Services Used in Small-Scale Sugarcane Production in Thailand." Sugar Tech 21, no. 4 (2019): 543-56.

3. Deepika, M, and M Asokhan. "A Study on Constraints Faced by the Farmers in Adoption and Marketing of Extra Long Staple Cotton Production Technology." Asian Journal of Agricultural Extension, Economics \&Sociology (2019): 1-4.

4. Jha, B. K., et al. "AN EVALUATION OF YIELD POTENTIAL OF RICE (Oryza Sativa) GENOTYPES UNDER CONSERVATION AGRICULTURAL PRACTICES IN EASTERN HILL PLATEAU REGION OF INDIA." International Journal of Agricultural Science \& Research 9.4 (2019): 239-244.

5. HOLEYANNAVAR, ATMANAND G., and DR VINAYAK M. BANKAPUR. "INFORMATION SEEKING BEHAVIOUR OF STUDENTS OF PHYSIOTHERAPY COLLEGE LIBRARIES IN KARNATAKA: A STUDY." International Journal of Library Science and Research (IJLSR)7.4, Aug 2017, 31-38

6. Katkar, VJ. "A Study of Adoption of Mango Production Technology in Akole Tahsil of Ahmednagar District." Mahatma Phule Krishi Vidyapeeth, Rahuri, 2001. 
7. Kumbhare, NV, and K Singh. "Adoption Behaviour and Constraints in Wheat and Paddy Production Technologies." Indian Research Journal of Extension Education 11, no. 3 (2016): 41-44.

8. Mehta, BM, and Madhuri Sonawane. "Entrepreneurial Behaviour of Mango Growers of Valsad District of Gujarat State." Indian Research Journal of Extension Education 12, no. 1 (2016): 78-82.

9. NAG, NAUKESWAR, J. P. Srivastava, and BIBHU SANTOSH BEHERA. "IMPACT OF PARTICIPATORY SEED PRODUCTION PROGRAMME ON KNOWLEDGE LEVEL OF PADDY SEED PRODUCERS UNDER RASTRIYA KRISHI VIKAS YOJONA (RKVY) ON JUNAGARH BLOCK OF KALAHANDI DISTRICT (ODISHA)." International Journal of Agricultural Science and Research 5.6 (2015): 239-246.

10. Rudra, Ashok, and Madan Mohan Mukhopadhyay. "Marketing Behaviour of Big, Medium and Small Farmers." Economic and Political Weekly (1973): 1199-202.

11. Sandeep, Chouhan, SRK Singh, AK Pande, and US Gautam. "Adoption Dynamics of Improved Sugarcane Cultivation in Madhya Pradesh." Indian Research Journal of Extension Education 13, no. 2 (2013): 26-30.

12. SHARMA, GARIMA. "A CRITICAL STUDY OF THE BIOLOGY CURRICULUM AT SENIOR SECONDARY STAGE WITH RESPECT TO LIFE SKILLS EDUCATION AND THE HIVIAIDS EDUCATION." IASET: International Journal of Library \& Educational Science (IASET: IJLES)2.3, Apr - May 2016; 1-10 
